\title{
Validation of a Simple and Rapid Method for Isolating Genomic DNA from Medicinal and Aromatic Plants for Subsequent Polymerase Chain Reaction
}

\author{
Vikash Kumar, Abhishek Prasad, Chandan Roy and Tirthartha Chattopadhyay*
}

Department of Plant Breeding and Genetics, Bihar Agricultural College, Bihar Agricultural University, Sabour, Bhagalpur, Bihar-813210, India

*Corresponding author

\begin{tabular}{|l|}
\hline K e y w o r d s \\
$\begin{array}{l}\text { ISSR, Medicinal and } \\
\text { aromatic plants, } \\
\text { Polymerase chain } \\
\text { reaction, Rapid DNA } \\
\text { isolation, Secondary } \\
\text { metabolites }\end{array}$ \\
\hline Article Info \\
\hline $\begin{array}{l}\text { Accepted: } \\
\text { 15 July 2018 } \\
\text { Available Online: } \\
\text { 10 August } 2018\end{array}$ \\
\hline
\end{tabular}

A B S T R A C T
The robust technique of polymerase chain reaction (PCR) has revolutionized the field of plant molecular biology and has made the molecular characterization of crop plants easy, rapid and reproducible. Only a minute amount of input genomic DNA is required in PCR. But, the isolated DNA must be free from different contaminants, which can potentially act as PCR inhibitors. The efficiency of PCR might be reduced in case of the medicinal and aromatic plants, due to the presence of biomolecules acting as PCR inhibitors. Hence the present study reports the applicability of a simple and rapid method for isolating genomic DNA from medicinal and aromatic plants, which can be successfully applied for PCRbased genotyping of these plants. Using a modified form of the detergent (SDS)-potassium acetate method, genomic DNA from the mature leaf tissues of 7 different medicinal and aromatic plants, viz., slender dwarf morning-glory (Evolvulus alsinoides L.), horse mint (Mentha longifolia L.), centella (Centella asiatica L.), brahmi (Bacopa monnieri L.), ashwagandha (Withania somnifera L.), vasaka (Adhatoda vasica Nees.) and sarpgandha (Rauwolfia serpentina L.) was isolated and PCR was carried out with different inter short sequence repeat (ISSR) primers. Gel electrophoresis revealed the presence of distinguishable sharp amplicons, prompting us to advocate the utility of this method for genotyping of medicinal and aromatic plants.

\section{Introduction}

The application of DNA technology in plant molecular biology is attracting many researchers to do lots of work for increasing the production, conservation and genetic improvement of rare and endangered plant species. The medicinal and aromatic plants contain several important secondary metabolites such as alkaloids, flavanoids, phenols, gummy polysaccharides, terpenes and quinines, which have huge applications as therapeutic, cosmetic, food additives, pesticides, and many more. The genetic improvement of these crops should be given priority, where modern techniques, like marker assisted selection (MAS) have to be adopted. With the invention of polymerase chain reaction (PCR), molecular characterization of plants has become easy, rapid and reproducible. In PCR, a minute but good quality genomic DNA is required as a template. But presence of different metabolites in medicinal and aromatic plants has remained 
as a bottleneck in the isolation of good quality of genomic DNA, PCR reaction, cloning and other downstream applications. Presence of polysaccharides in the isolated genomic DNA of medicinal and aromatic plant make DNA viscous and glue-like, that stick to the wells during gel electrophoresis and becomes nonamplifiable in the polymerase chain reaction (PCR) by inhibiting TaqDNA polymerase activity and also interfere the activities of several other biological enzymes like DNA ligases and restriction endonucleases (Porebski et al., 1997; Barnell et al., 1998; Diadema et al., 2003; Varma et al., 2007). The presence of polyphenols, released from vacuoles during cell lysis, undergo irreversible interaction with nucleic acid causing browning of the DNA (Varma et al., 2007). Hence, attempts have been made to optimize several protocols to isolate pure and high quality of genomic DNA from medicinal and aromatic plant (Doyle and Doyle, 1987; Haymes, 1996; Scott and Playford, 1996; Khanuja et al., 1999; Sharma et al., 2000; Pirttilä et al., 2001; Shepherd et al., 2002; Mogg and Bond, 2003).

Here we validate a rapid and reproducible method (Kumar et al., 2017) for isolating genomic DNA from 7 different medicinal and aromatic plants. The utility of the method was tested through subjecting the isolated genomic DNA to PCR using different inter short sequence repeat (ISSR) primers. The presence of distinguishable sharp amplicons, as revealed through gel electrophoresis advocates the applicability of this method for genotyping of medicinal and aromatic plants at molecular level.

\section{Materials and Methods}

\section{Plant materials}

Leaf tissues were collected from 7 different medicinal and aromatic plants viz., slender dwarf morning-glory (Evolvulus alsinoides
L.), horse mint (Mentha longifolia L.), centella (Centella asiatica L.), brahmi (Bacopa monnieri L.), ashwagandha (Withania somnifera L.), vasaka (Adhatoda vasica Nees.) and sarpgandha (Rauwolfia serpentina L.) from Botanical garden of Bihar Agricultural University, Sabour, Bhagalpur.

\section{DNA isolation procedure}

For the preparation of good quality of genomic DNA, $\sim 50 \mathrm{mg}$ fresh leaf samples were collected in $1.5 \mathrm{ml}$ microcentrifuge tubes. The tissue was homogenized through crushing, using a micro-pestle in $400 \mu \mathrm{l}$ of buffer [100 mM Tris-Cl, $50 \mathrm{mM}$ EDTA, 500 $\mathrm{mM} \mathrm{NaCl}, 1 \%(\mathrm{w} / \mathrm{v})$ SDS and $0.1 \%(\mathrm{v} / \mathrm{v}) \beta-$ Mercaptoethanol]. Next, $128 \mu \mathrm{l}$ of $5 \mathrm{M}$ potassium acetate was added and the mixture was centrifuged at $10,000 \mathrm{rpm}$ for $10 \mathrm{~s}$. Then $300 \mu$ l supernatant was collected in a fresh microcentrifuge tube and equal volume $(300 \mu \mathrm{l})$ of chilled isopropanol was added. Following mixing, the sample was centrifuged at $10,000 \mathrm{rpm}$ for 10 sto precipitate the genomic DNA. The DNA pellet was then washed with $200 \mu$ lof $70 \%$ (v/v) ethanol, dried and dissolved in sterile water.

\section{PCR amplification}

Polymerase chain reaction (PCR) amplification of isolated genomic DNA was carried out in a total $10 \mu \mathrm{l}$ volume. The PCR reaction mixture contained template DNA (1 $\mu 1$ ), 1X PCR buffer with $\mathrm{MgCl}_{2}$ (Xcelris), $0.2 \mathrm{mM}$ of dNTP mix (Xcelris), $0.1 \mu \mathrm{M}$ of primer and $1 \mathrm{U}$ of TaqDNA polymerse (Xcelris). PCR amplification was performed in an automated thermal cycler (Veriti 96 well thermal cycler, Applied Biosystems) using the thermal profile consisting of an initial denaturation at $94^{\circ} \mathrm{C}$ for $4 \mathrm{~min}$ followed by 45 cycles of $30 \mathrm{~s}$ at $94^{\circ} \mathrm{C}, 60 \mathrm{~s}$ at $36^{\circ} \mathrm{C}$ annealing temperature, $120 \mathrm{~s}$ at $72^{\circ} \mathrm{C}$ and ended with final extension at $72^{\circ} \mathrm{C}$ for $10 \mathrm{~min}$ followed by 
hold at $4{ }^{\circ} \mathrm{C}$. The sequence of the ISSR primers reported earlier (Lu et al., 2009) and used in this study is presented in Table 1. The amplicons were subjected to $1.2 \% \quad(\mathrm{w} / \mathrm{v})$ agarose gel electrophoresis in presence of ethidium bromide and imaged in gel documentation system (Genei, Bangalore).

\section{Results and Discussion}

The rapid DNA isolation procedure adopted in this study allowed the isolation of genomic DNA from the leaf tissues in $\sim 20 \mathrm{~min}$ time. All the isolated genomic DNA were found to give amplification with the 6 ISSR markers, tested in this study. The amplicon profiles, obtained in this study are summarized in Figure 1. All the primers gave distinguishable banding pattern. Furthermore, the banding pattern of the 7 medicinal and aromatic plant samples was found to be distinct from each other for all the 6 ISSR markers tested. This indicated the efficiency and quality of isolated genomic DNA from medicinal and aromatic plants. The scorable and distinct bands were then taken for analysis, where it was found that in case of the ISSR 4F primer, total 35 amplicons were obtained, where the amplicon size ranged from $\sim 1000$ bp (vasaka) to $\sim 247$ bp (centella). A total of 29 amplicons (ranging from $\sim 1014 \mathrm{bp}$ in sarpagandha to $\sim 277 \mathrm{bp}$ in brahmi) were generated in case of the ISSR $8 \mathrm{~F}$ primer, whereas the total number of amplicons generated was 29 (ranging from $~ 943$ bp in SD morning-glory to $\sim 282 \mathrm{bp}$ in brahmi) in case of the ISSR $22 \mathrm{~F}$ primer. In a similar manner, the ISSR primer $43 \mathrm{~F}, 44 \mathrm{~F}$ and $51 \mathrm{~F}$ generated a total number of 24,29 and 22 amplicons, with a range of $\sim 1060$ bp (in sarpagandha) to $\sim 254 \mathrm{bp}$ (in vasaka), 786 bp (in sarpagandha) to $\sim 275 \mathrm{bp}$ (in vasaka) and $\sim 700 \mathrm{bp}$ (in SD morning glory) to $261 \mathrm{bp}$ (in brahmi and ashwagandha), respectively. Thus, the genomic DNA isolated in this rapid method was found to be suitable for downstream application in genotyping of medicinal and aromatic plants using PCR.

Fig.1 Amplicon profile of isolated genomic DNA from 7 medicinal and aromatic plants using 6 different ISSR primers. A. Amplification with ISSR 4 primer. B. Amplification with ISSR 8 primer. C. Amplification with ISSR 22 primer. D. Amplification with ISSR 43 primer. E. Amplification with ISSR 44 primer. F. Amplification with ISSR 51 primer. $L=100$ bp DNA ladder (Genei, Bangalore)
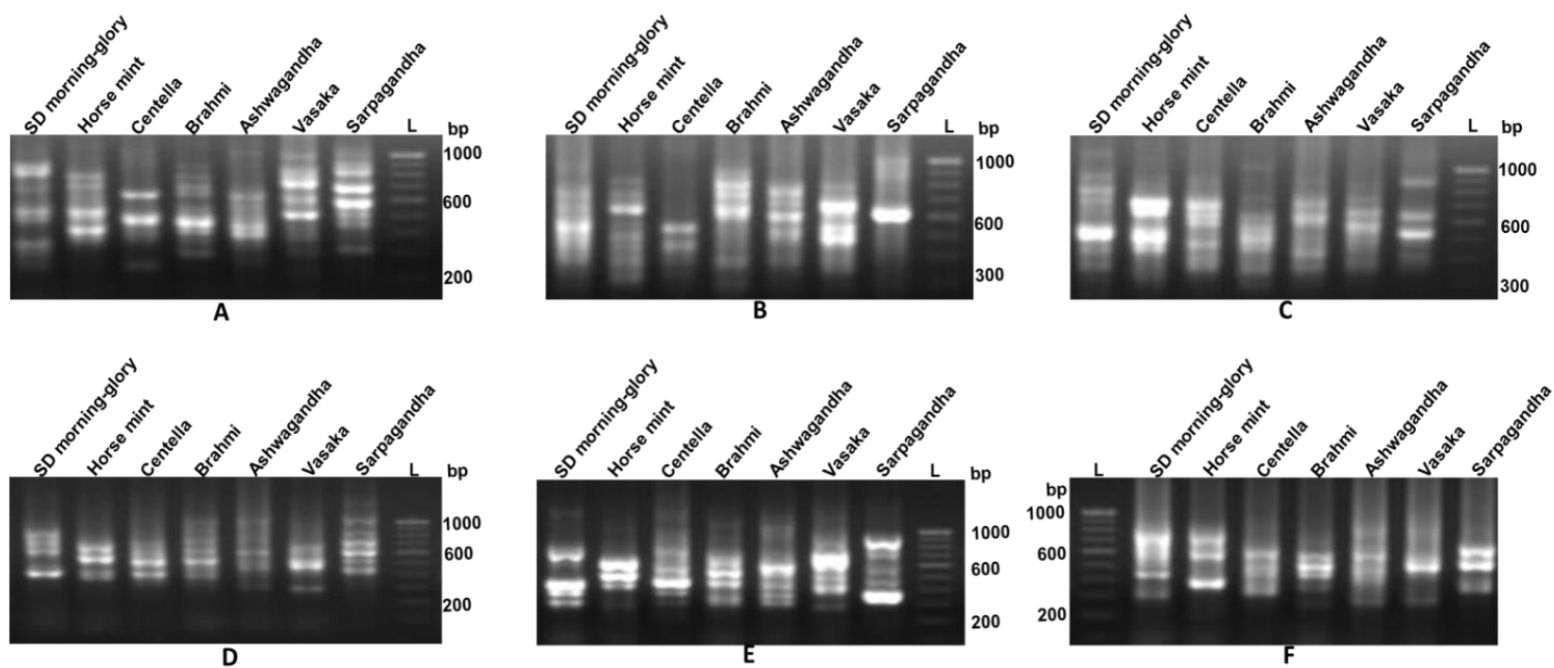
Table.1 Sequence of the ISSR primers used in this study

\begin{tabular}{|c|c|}
\hline ISSR Primer & Sequence $\left(\mathbf{5}^{\prime} \mathbf{3}^{\prime} \mathbf{)}\right.$ \\
\hline ISSR 4 & ACACACACACACACACACACAG \\
\hline ISSR8 & ATGATGATGATGATGATG \\
\hline ISSR22 & ACACACACACACACACAA \\
\hline ISSR43 & ACACACACACACACACCT \\
\hline ISSR44 & ACACACACACACACACGA \\
\hline ISSR51 & TGTGTGTGTGTGTGTGAT \\
\hline
\end{tabular}

A minute amount of isolated genomic DNA was found to be sufficient for PCR, enabling the researcher to use the isolated DNA for several hundred independent PCRs. In this method, the isolated genomic DNA was found to remain stable for several months, when stored at $-20^{\circ} \mathrm{C}$. Hence, we advocate the applicability of this simple, rapid and reproducible method of DNA isolation for molecular characterization of medicinal and aromatic plants through PCR.

\section{Acknowledgement}

The authors acknowledge the supports provided by Bihar Agricultural University, Sabour, Bhagalpur. AP thanks Bihar Agricultural University, Sabour, Bhagalpur for providing scholarship. Financial supports, in terms of project grant (SB/YS/LS-74/2013) from the Science and Engineering Research Board (SERB), Department of Science and Technology (DST), Govt. of India is acknowledged. The authors also thank Prof. P.K. Singh, Chairman, Department of Plant Breeding and Genetics, Bihar Agricultural College, Bihar Agricultural University, Sabour, Bhagalpur for proving help, support and suggestions. This article bears BAU COMMUNICATION NO.: 438/2018.

\section{References}

Barnell, P., Blanchard, A.N., Bryant, J.A., Smirnoff, N. and Weir, A.F. 1998. Isolation of DNA from the highly mucilaginous succulent plant Sedum telephium Plant Mol. Biol. Rep. 16, 133-138.

Diadema, K., Baumel, A., Lebris, M. and Affre, L. 2003.Genomic DNA isolation and amplification from callus culture in succulent plants, Carpobrotus species (Aizoaceae) Plant Mol. Biol. Rep. 21, 173-173.

Doyle, J.J. and Doyle, J.L. 1987. A rapid DNA isolation procedure for small quantities of fresh leaf tissue. Phytochem. Bull. 19:11-15.

Haymes, K.M. 1996. Mini-prep method suitable for a plant breeding program. Plant Mol. Biol. Rep. 14, 280-284.

Khanuja, S.P.S., Shasany, A.K., Darokar, M.P. and Kumar, S. 1999. Rapid isolation of DNA from dry and fresh samples of plants producing large amounts of secondary metabolites and essential oils. Plant Mol. Biol. Rep.17, $1-7$.

Kumar, V., Kumar, P. and Chattopadhyay, T. 2017. A rapid and reproducible method for isolating genomic DNA from a few crop plants suitable for polymerase chain reaction-based genotyping. J. Appl. Nat. Sci. 9, 1119-1122.

Lu, X., Liu, L., Gong, Y., Zhao, L., Song, X., and Zhu, X. 2009. Cultivar identification and genetic diversity analysis of broccoli and its related species with RAPD and ISSR markers Sci. Hort. 122, 645-648. 
Mogg, R.J. and Bond, J.M. 2003.A cheap, reliable and rapid method of extracting high quality DNA from plants. Mol. Ecol. Notes 3, 666-668.

Pirttilä, M.A., Hirsikorpi, M., Kämäräinen, T., Jaakola, L. and Hohtola, A. 2001.DNA isolation methods for medicinal and aromatic plants. Plant Mol. Biol. Rep. 19, 273-273.

Porebski, S., Bailey, L.G. and Baum, B.R. 1997.Modification of a CTAB DNA extraction protocol for plants containing high polysaccharide and polyphenol components. Plant Mol. Biol. Rep. 15, $8-15$.

Scott, K.D. and Playford, J. 1996. DNA extraction technique for $\mathrm{PCR}$ in rain forest plant species. Biotechniques 20:974-979.

Sharma, K.K., Lavanya, M., and Anjaiah, V. 2000. A method for isolation and purification of peanut genomic DNA suitable for analytical applications. Plant Mol. Biol. Rep. 18, 393-393.

Shepherd, M., Cross, M., Stokoe, R.L. and Scott, L.J. 2002. High throughput DNA extraction from forest trees. Plant Mol. Biol. Rep. 20, 425-425.

Varma, A., Padh, H., and Shrivastava, N. 2007. Plant genomic DNA isolation: an art or a science. Biotechnol. J. 2, 386392.

\section{How to cite this article:}

Vikash Kumar, Abhishek Prasad, Chandan Roy and Tirthartha Chattopadhyay. 2018. Validation of a Simple and Rapid Method for Isolating Genomic DNA from Medicinal and Aromatic Plants for Subsequent Polymerase Chain Reaction. Int.J.Curr.Microbiol.App.Sci. 7(08): 2562-2566. doi: https://doi.org/10.20546/ijcmas.2018.708.263 